\title{
Stability of human gallbladder bile: Effect of freezing
}

\author{
Paul Janowitz $\mathrm{MD}^{1}$, Richard Mason $\mathrm{MD}^{2}$, Wolfgang Kratzer $\mathrm{MD}^{3}$
}

P Janowitz, R Mason, W Kratzer. Stability of human gallbladder bile: Effect of freezing. Can J Gastroenterol 2001;15(6):363366. In the present study, the stability of the most essential biliary parameters of human gallbladder bile at $-18^{\circ} \mathrm{C}$ was examined over several months. In 12 patients with gallstone disease (10 female, two male; $52.1 \pm 13.3$ years of age), bile was obtained through fine needle puncture of the gallbladder under local anesthetic. The concentrations of total lipids, cholesterol, phospholipids and bile acids, and the cholesterol saturation index and crystal appearance time were determined before and after freezing over a mean period of $4.38 \pm 2.9$ months. Gallbladder bile obtained by fine needle puncture has proved to be of excellent quality. The total lipid concentration was unchanged before $(8.30 \pm 4.16 \mathrm{~g} / \mathrm{dL})$ and after freezing $(9.16 \pm 4.54 \mathrm{~g} / \mathrm{dL}$, $\mathrm{P}=0.6027$ ). The biliary cholesterol, phospholipids and bile acid concentrations, and cholesterol saturation index showed no statistically significant differences before and after freezing. A significant difference arises in the context of subdivision of the group to the nucleation time. Before freezing, most patients had a nucleation time between five and eight days, which shortened to between one and four days after thawing $(\mathrm{P}=0.0100)$.

The authors conclude that, with the exception of the nucleation time, human gallbladder bile can be stored at $-18^{\circ} \mathrm{C}$ for four months with stability of major lipid components.

\section{L'effet du gel sur la stabilité de la bile humaine, prélevée dans la vésicule}

RÉSUMÉ : La présente étude avait pour objet la stabilité des principales caractéristiques de la bile humaine, prélevée dans la vésicule et conservée à une température de $-18{ }^{\circ} \mathrm{C}$; l'analyse s'est échelonnée sur plusieurs mois. Une ponction de la vésicule pratiquée sous anesthésie locale au moyen d'une aiguille fine a permis le prélèvement de bile chez 12 patients (10 femmes, 2 hommes; 52,1 $\pm 13,3$ ans) souffrant de lithiase biliaire. On a procédé à différentes mesures avant et après le gel, et ce, sur une période moyenne de 4,38 $\pm 2,9$ mois; il s'agit des taux de lipides totaux, de cholestérol, de phospholipides et d'acides biliaires ainsi que du degré de saturation du cholestérol et du temps d'apparition des cristaux. La bile prélevée s'est avérée d'excellente qualité. Le taux de lipides totaux est resté inchangé avant et après le gel $(8,30 \pm 4,16 \mathrm{~g} / \mathrm{dl}$ contre $9,16 \pm 4,54 \mathrm{~g} / \mathrm{dl} ; \mathrm{P}=0,6027)$. Les taux de cholestérol biliaire, de phospholipides et d'acides biliaires, de même que le degré de saturation du cholestérol, n'ont pas subi de différence significative sur le plan statistique. Le seul paramètre qui a montré une différence significative est le temps de nucléation. Avant le gel, ce temps oscillait entre cinq et huit jours chez la plupart des patients mais, après le dégel, il est passé de un à quatre jours $(\mathrm{P}=0,0100)$. Les auteurs en arrivent à la conclusion que la bile humaine prélevée dans la vésicule peut être conservée à une température de $-18{ }^{\circ} \mathrm{C}$ durant quatre mois tout en maintenant ses principales caractéristiques, sauf en ce qui concerne le temps de nucléation.

Key Words: Bile acids; Cholesterol saturation index; Diagnosis; Gallstones; Nucleation time; Puncture

${ }^{1}$ Department of Internal Medicine, Krankenhaus Burg, Burg; ${ }^{2}$ University of Ulm, Department of Internal Medicine I, Ulm, Germany Correspondence and reprints: Dr Paul Janowitz, Krankenhaus Burg, Academic Teaching Hospital of the University of Magdeburg,

August-Bebel-Straße 55a, 39288 Burg, Germany. Telephone +00493921-96-1301, fax+00493921-96-1340, e-mail Janowitz@freenet.de Received for publication September 26, 2000. Accepted January 22, 2001 
$\mathrm{T}$ he ongoing progress in the conservative therapy of gallstone disease has focused attention on the importance of adequate patient selection (1-6). Human gallbladder bile samples are often used in biliary research. The presence of cholesterol crystals and the determination of nucleation time (NT) in the gallbladder bile are the best methods of distinguishing between cholesterol and pigment gallstones, and correlate well with computed tomographic analysis $(1,7,8)$. Furthermore, microscopic examination of bile is easier, quicker and cheaper than biochemical analysis of bile or computed tomography of the gallbladder (9-12). An immediate examination of the gallbladder bile at $37^{\circ} \mathrm{C}$ is considered a prerequisite for a microscopic examination. Conjugated bilirubin remains relatively stable at $-70^{\circ} \mathrm{C}$ over several months but degrades rather quickly at $-15^{\circ} \mathrm{C}$ (13). Other biliary parameters, such as bile acids, phospholipids and cholesterol, are stable at $-30^{\circ} \mathrm{C}$ over a week (14). The aim of the present study was to examine the stability of the major lipid components at $-18^{\circ} \mathrm{C}$ over several months.

\section{PATIENTS AND METHODS}

In 12 patients with gallstone disease (10 female, two male; $52.1 \pm 13.3$ years of age; five cholesterol and seven mixed pigment gallstones), bile was obtained through fine needle puncture of the gallbladder under local anesthetic. In one female patient, the gallbladder puncture was performed twice.

Bile aspiration was performed for research purposes; therefore, appropriate informed consent was obtained from each patient. Patients with a history of chronic or acute cholecystitis, or sonographically or computed tomographically confirmed cholecystitis were excluded from the study.

The fine needle puncture of the gallbladder was performed between 08:00 and 09:00 after a $12 \mathrm{~h}$ fasting period. The method has been described elsewhere $(1,3,15)$. The transducer was equipped with a commercially available lateral puncture attachment to provide a biopsy guide for all punctures. To avoid bile leakage, the gallbladder bile was completely aspirated in each patient. Aerobic and anaerobic cultures were performed immediately after aspiration. The positive samples contaminated by bacteria have been excluded from the present study. The bile samples were ultracentrifuged at $100,000 \mathrm{~g}\left(37^{\circ} \mathrm{C}\right)$ for $2 \mathrm{~h}$. The isotropic (cholesterol- and liquid crystal-free) interphase was incubated at $37^{\circ} \mathrm{C}$ afterwards. The NT was determined by applying the method of Holan et al (8), defined as the earliest time required for detection of cholesterol monohydrate crystals in aliquots of the incubated isotropic phase, expressed in days. One drop of incubated aliquots was examined daily on a glass slide at a magnification of $100 \times$ to $400 \times$ under crossed polars (Leitz, Germany). Total biliary bile acids were determined by enzymatic testing (Sterognost-3-alpha, Nycomed N-0401 Oslo 4, Norway). Bile acid analysis was carried out using high performance liquid chromatography with dexamethasone as the internal standard (16). The biliary cholesterol and phospholipid concentrations were determined using an enzymatic colour
TABLE 1

Biliary parameters before and after freezing at $-18^{\circ} \mathrm{C}$ over a mean period of $4.38 \pm 2.9$ months $(n=13)$

\begin{tabular}{lccc}
\hline & Before & After & P \\
\hline $\begin{array}{l}\text { Nucleation time (days) } \\
\begin{array}{l}\text { Cholesterol saturation } \\
\text { index }\end{array}\end{array}$ & $7.9 \pm 7.5$ & $5.4 \pm 7.9$ & 0.4236 \\
$\begin{array}{l}\text { Total lipid concentration } \\
\text { (g/dL) }\end{array}$ & $8.3 \pm 4.1$ & $9.1 \pm 4.5$ & 0.6027 \\
Biliary bile acids (mmol/L) & $107.1 \pm 56.0$ & $114.3 \pm 61.0$ & 0.7567 \\
Biliary bile acids (mol\%) & $68.6 \pm 3.8$ & $67.0 \pm 5.5$ & 0.4171 \\
Phospholipids (mmol/L) & $36.4 \pm 14.5$ & $37.9 \pm 18.9$ & 0.8195 \\
Phospholipids (mol\%) & $21.5 \pm 1.8$ & $22.7 \pm 3.3$ & 0.2808 \\
Biliary cholesterol (mmol/L) & $13.9 \pm 6.5$ & $16.0 \pm 7.8$ & 0.4768 \\
Biliary cholesterol (mol\%) & $9.8 \pm 2.7$ & $10.2 \pm 2.8$ & 0.7257 \\
\hline
\end{tabular}

test (CHOD-PAP method, Boehringer Mannheim, Germany). The total lipid concentration of bile (TLCO) is the sum of the cholesterol, bile acid and phospholipid concentrations, and is expressed in $\mathrm{g} / \mathrm{dL}$ (conversion factors: cholesterol $386 \mathrm{~g} / \mathrm{mol}$, bile acids $495 \mathrm{~g} / \mathrm{mol}$, phospholipids $735 \mathrm{~g} / \mathrm{mol}$ ). The cholesterol saturation index, as defined by Admirand and Small (17), was calculated using a microcomputer program described by Kuroki et al (18). The rest of each gallbladder bile sample was stored at $-18^{\circ} \mathrm{C}$ over a mean period of $4.38 \pm 2.9$ months (range 0.3 to 13 months). After thawing at room temperature over $12 \mathrm{~h}$, the bile samples were ultracentrifuged at $100,000 \mathrm{~g}\left(37^{\circ} \mathrm{C}\right)$ for $2 \mathrm{~h}$; the isotropic interphase was then incubated at $37^{\circ} \mathrm{C}$, and the renewed determination of the biliary bile parameters was carried out according to the methods described above.

All data are presented as mean \pm SD. Statistical significance was calculated using the Student's $t$ test for dependent random samples.

\section{RESULTS}

The gallbladder puncture was successful in all 12 patients (100\%). Complications due to the fine needle puncture, such as bleeding, bile leak or inflammation, were not observed. The TLCO was unchanged before $(8.30 \pm 4.16 \mathrm{~g} / \mathrm{dL}$; range 1.38 to $15.3 \mathrm{~g} / \mathrm{dL})$ and after freezing $(9.16 \pm 4.54 \mathrm{~d} / \mathrm{dL}$; range 1.41 to $16.4 \mathrm{~g} / \mathrm{dL})(\mathrm{P}=0.6027)$. There was no significant correlation between lipid concentration and the length of the storage period $(r=-0.0704, \mathrm{P}=0.8194)$. Other biliary components also showed no statistically significant differences before and after freezing (Tables 1 and 2).

The NT was not significantly different in the complete group before freezing with $7.9 \pm 7.5$ days and after freezing with $5.5 \pm 7.9$ days $(\mathrm{P}=0.4236)$; however, individual fluctuations have been observed (Figure 1). A significant difference arises in the context of subdivision of the group for the NT $\left(\mathrm{P}=0.0100, \chi^{2}\right.$ test). Before freezing, most patients had an NT of between five and eight days. After thawing, this peak lay between one and four days. 
TABLE 2

Percentage of biliary bile acids before and after freezing $(n=13)$

\begin{tabular}{lccc}
\hline $\begin{array}{l}\text { Biliary bile } \\
\text { acids (mol\%) }\end{array}$ & Before & After & P \\
\hline Cholic acid & $29.6 \pm 6.8$ & $30.7 \pm 6.3$ & 0.6581 \\
Glycocholic acid & $18.9 \pm 5.7$ & $20.4 \pm 3.4$ & 0.4274 \\
Taurocholic acid & $10.8 \pm 6.0$ & $10.3 \pm 4.3$ & 0.8005 \\
Chenodeoxycholic acid & $36.0 \pm 10.3$ & $35.9 \pm 10.3$ & 0.9760 \\
Glycochenodeoxycholic acid & $26.9 \pm 8.5$ & $26.8 \pm 8.5$ & 0.9673 \\
Taurochenodeoxycholic acid & $8.6 \pm 3.7$ & $9.1 \pm 3.9$ & 0.7555 \\
Deoxycholic acid & $28.8 \pm 9.6$ & $28.8 \pm 9.5$ & 0.9903 \\
Glycodeoxycholic acid & $22.7 \pm 8.6$ & $22.7 \pm 8.4$ & 0.9891 \\
Taurodeoxycholic acid & $6.1 \pm 3.4$ & $6.1 \pm 3.4$ & 0.9504 \\
Lithocholic acid & $2.6 \pm 1.6$ & $2.6 \pm 1.7$ & 0.9631 \\
Glycolithocholic acid & $1.5 \pm 1.2$ & $1.4 \pm 0.8$ & 0.6641 \\
Taurolithocholic acid & $1.0 \pm 0.7$ & $1.2 \pm 1.0$ & 0.5173 \\
Ursodeoxycholic acid & $3.0 \pm 2.8$ & $1.9 \pm 1.7$ & 0.2353 \\
Glycoursodeoxycholic acid & $1.1 \pm 1.2$ & $1.0 \pm 1.0$ & 0.8011 \\
Tauroursodeoxycholic acid & $1.8 \pm 2.9$ & $0.8 \pm 1.7$ & 0.2860 \\
\hline
\end{tabular}

\section{DISCUSSION}

In the present study, the stability of human gallbladder bile remained unaltered at $-18^{\circ} \mathrm{C}$ over a mean period of $4.38 \pm 2.9$ months. Cholesterol, phospholipids, bile acids, total lipid concentration and the cholesterol saturation index showed no trends or significant changes. Other studies had already shown that biliary components are stable at $-30^{\circ} \mathrm{C}$ over one week (14). In a study of porcine gallbladder bile, the $\mathrm{pH}$ and concentrations of total and ionized calcium, phospholipid, cholesterol and bile salts were stable over 17 days at $-17^{\circ} \mathrm{C}(19)$. The total bilirubin concentration was also stable at $-15^{\circ} \mathrm{C}(19)$.

The NT was the only parameter that showed clear individual fluctuations. Before freezing, most patients had an NT between five and eight days; after freezing this peak was between one and four days. In the initial stage of cholesterol gallstone formation, the nucleation of cholesterol monohydrate crystals occurs within the mucous gel (20). The results of other studies suggest that qualitative differences in individual proteins of gallbladder bile are responsible for nucleation-promoting activity in vitro (20-24). On the other hand, the purified apolipoproteins A-1 and A-2 are able to prolong the NT (25-27). Apolipoprotein A-1 stabilizes the nonmicellar fraction by forming an apolipoprotein A-1 and lipid complexed particle, resulting in prolonged cholesterol crystal nucleation (27). The close association of vesicles and crystals in human gallbladder bile supports the contention that vesicles are important in the initial nucleation of cholesterol monohydrate crystals (28). Either the glycoprotein activity becomes strengthened after freezing or the activity of the nucleation inhibitor factors is reduced. In the present study, the glyco-

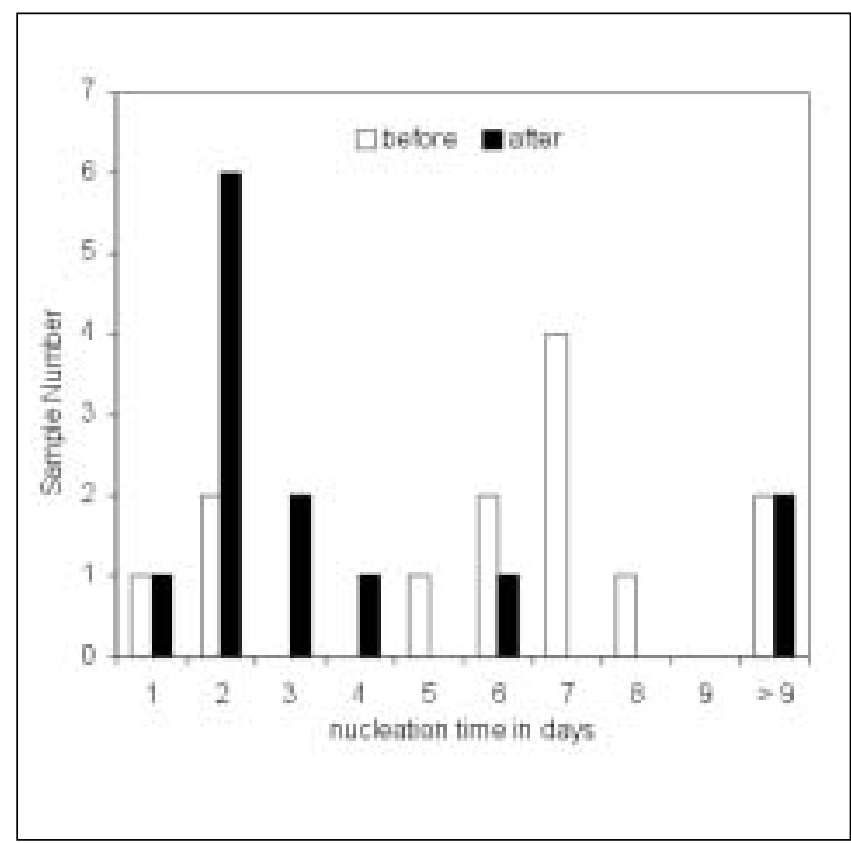

Figure 1) Distribution of the nucleation time in days before and after freezing $(n=13)$

proteins and the apolipoproteins were not measured; therefore, it is not possible to comment on this. The prerequisite for a longer storage of the gallbladder bile is presumably an extraction of the samples without bacterial contamination. In another study, the gallbladder bile was contaminated in $13.3 \%$ of patients with gallstones without history and without evidence of acute or chronic cholecystitis (29).

\section{CONCLUSION}

With the exception of the NT, human gallbladder bile can be stored at $-18^{\circ} \mathrm{C}$ for four months with stability of major lipid components.

\section{REFERENCES}

1. Janowitz P, Swobodnik W, Wechsler JG, Zoeller A, Kuhn K, Ditschuneit H. A comparison of gallbladder bile and endoscopically obtained duodenal bile. Gut 1990;31:1407-10.

2. Ahrendt SA, Magnuson TH, Pitt HA, Lillemoe KD. Effect of cholecystectomy on gallbladder bile composition. Dig Dis Sci 1992;37:1232-5.

3. Hussaini SH, Kennedy C, Pereira SP, Wass JAH, Dowling RH. Ultrasound-guided percutaneous fine needle puncture of the gallbladder for studies of bile composition. Br J Radiol 1995;68:271-6.

4. Keulemans YC, Mok KS, de Wit LT, Gouma DJ, Groen AK. Hepatic bile versus gallbladder bile: a comparison of protein and lipid concentration and composition in cholesterol gallstone patients. Hepatology 1998;28:11-6.

5. Choudhuri G, Agarwal DK, Saraswat VA, Negi TS, Saxena R, Kapoor VK. Is duodenal bile representative of gallbladder bile? A comparative study. Scand J Gastroenterol 1993;28:920-3.

6. Janowitz P, Wechsler JG, Janowitz A, Kuhn K, Swobodnik W, Ditschuneit H. Nucleation time, cholesterol saturation index, and biliary bile acid pattern. A comparison in responders and nonresponders to systemic litholysis with bile acids. Scand J Gastroenterol 1991;26:367-73.

7. Burnstein MJ, Ilson RG, Petrunka CN, Taylor RD, Strassberg SM. Evidence for a potent nucleating factor in the gallbladder bile of patients with cholesterol gallstones. Gastroenterology 1983;83:801-7. 
8. Holan KR, Holzbach RT, Herrmann RE, Cooperman AM, Claffey WJ. Nucleation time: A key factor in the pathogenesis of cholesterol gallstone disease. Gastroenterology 1979;77:611-7.

9. Baron RL, Rohrmann CA, Lee SP, Shuman WP, Teefey SA. $\mathrm{CT}$ evaluation of gallstones in vitro: correlation with chemical analysis. AJR Am J Roentgenol 1988;151:1123-8.

10. Janowitz P, Zoeller A, Swobodnik W, Wechsler JG, Schumacher KA, Ditschuneit H. Computed tomography evaluation of radiolucent gallstones in vivo. Gastrointest Radiol 1990;15:58-60.

11. Brakel K, Lameris JS, Nijs HG, Terpstra OT, Steen G, Blijenberg BC. Predicting gallstone composition with $\mathrm{CT}$ : in vivo and in vitro analysis. Radiology 1990;174:337-41.

12. Pereira SP, Veysey MJ, Kennedy C, Hussaini SH, Murphy GM, Dowling RH. Gallstone dissolution with oral bile acid therapy. Importance of pretreatment CT scanning and reasons for nonresponse. Dig Dis Sci 1997;42:1775-82.

13. Doumas BT, Perry BW, Sasse EA, Straumfjord JV Jr. Standardization in bilirubin assays: Evaluation of selected methods and stability of bilirubin solutions. Clin Chem 1973;19:984-93.

14. Freeman JL, Meyer PD, DenBesten L. Effects of freezing and incubation on biliary lipid analysis. Proc Soc Exp Biol Med 1974;147:31-4.

15. Swobodnik W, Hagert N, Janowitz P, Wenk H. Diagnostic fine-needle puncture of the gallbladder with US guidance. Radiology 1991;178:755-8.

16. Swobodnik W, Klüppelberg U, Wechsler JG, Volz M, Normandin G, Ditschuneit H. Rapid and acurate reversed-phase high-performance liquid chromatographic determination of conjugated bile acids in human bile for routine clinical application. Therapeutic control during gallstone dissolution therapy. J Chromatogr 1985;339:263-71.

17. Admirand WH, Small DH. The physicochemical basis of cholesterol gallstone formation im man. J Clin Invest 1968;47:1043-52.

18. Kuroki S, Cohen IB, Carey MC, Mosbach EH. Rapid computation with the personal computer of the percent cholesterol saturation of bile samples. J Lipid Res 1986;27:442-6.
19. Chodash HB, Tsang TK, Pollack JM, Eisenman RE, Rege RM, Ostrow JD. Effect of temperature on stability of eight components of porcine gallbladder bile. Dig Dis Sci 1997;42:273-8.

20. Smith BF. Gallbladder mucin as a pronucleating agent for cholesterol monohydrate crystals in bile. Hepatology 1990;12:183S-6S.

21. Kibe A, Dudley MA, Halpern Z, Lynn MP, Breuer AC, Holzbach T. Factors affecting cholesterol monohydrat crystal nucleation time in model systems of supersaturated bile. J Lipid Res 1985;26:1102-11.

22. Harvey PR, Rupar CA, Gallinger S, Petrunka CN, Strassberg SM. Quantitative and qualitative comparison of gallbladder mucus glycoprotein from patients with and without gallstones. Gut 1986;27:374-81.

23. Gallinger S, Taylor RD, Harvey PR, Petrunka CN, Strasberg SM. Effect of mucus glycoprotein on nucleation time of human bile. Gastroenterology 1985;89:648-58.

24. Nakano A, Masuzawa S, Ogura K, et al. Effects of a concanavalin A-binding biliary glycoprotein on nucleation time of gallbladder bile. Gastroenterol Jpn 1990;25:88-92.

25. Sewell RB, Mao SJT, Kawamoto T, LaRusso NF. Apolipoproteins of high, low and very low density lipoproteins in human bile. J Lipid Res 1983;24:391-401.

26. Swobodnik W, Wenk H, Janowitz P, et al. Total biliary protein, mucus glycoproteins, cyclic-AMP, and apolipoproteins in the gallbladder bile of patients with cholesterol stones and stone-free controls. Scand J Gastroenterol 1991;26:771-8.

27. Tazuma S, Mizuno S, Sasaki H, et al. A study on the mechanisms whereby apolipoprotein A-1 (apo A-1) inhibits cholesterol crystal nucleation in human gallbladder bile. Nippon Shokakibyo Gakkai Zasshi 1991;88:1083-8.

28. Schriever CE, Juengst D. Association between cholesterolphospholipid vesicles and cholesterol crystals in human gallbladder bile. Hepatology 1989;9:541-6.

29. Janowitz P, Wechsler JG, Swobodnik W, Kuhn K, Kratzer W, Ditschuneit $\mathrm{H}$. The incidence of bactibilia in gallstone patients without evidence of chronic or acute cholecystitis. Am J Gastroenterol 1993;8:614-5. 


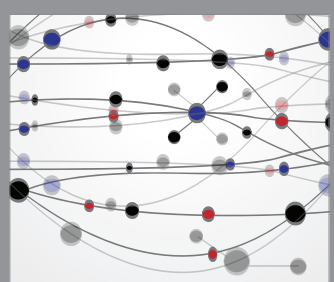

The Scientific World Journal
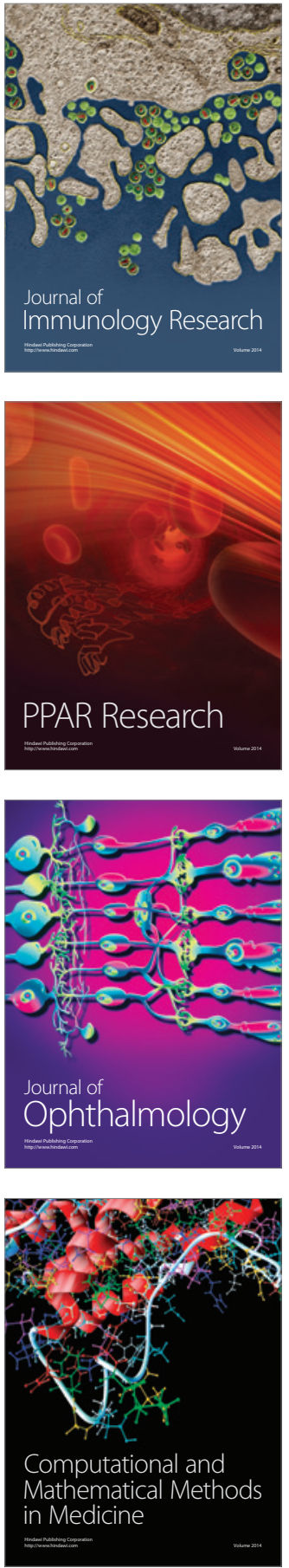

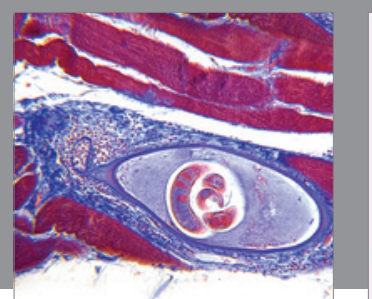

Gastroenterology Research and Practice

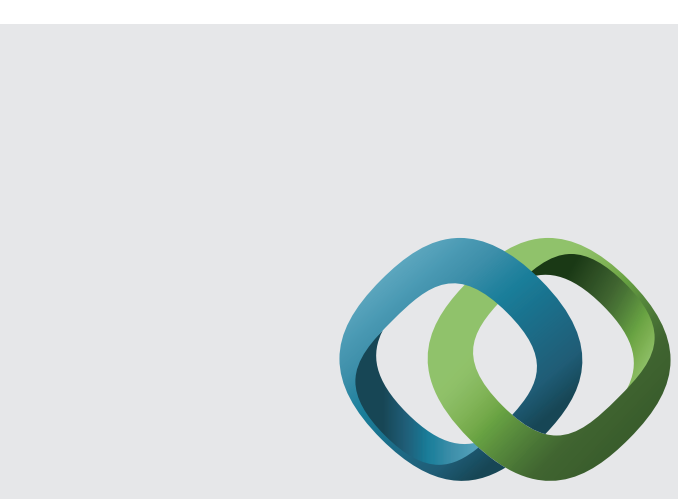

\section{Hindawi}

Submit your manuscripts at

http://www.hindawi.com
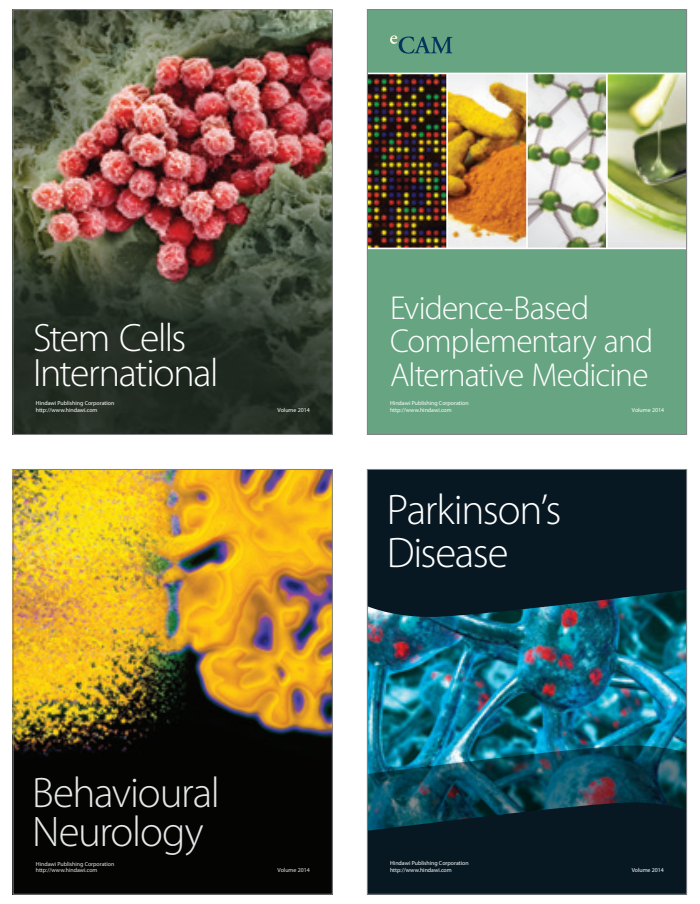
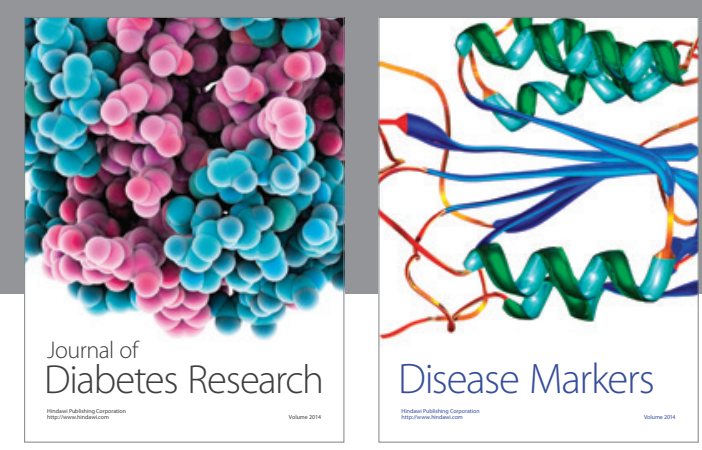

Disease Markers
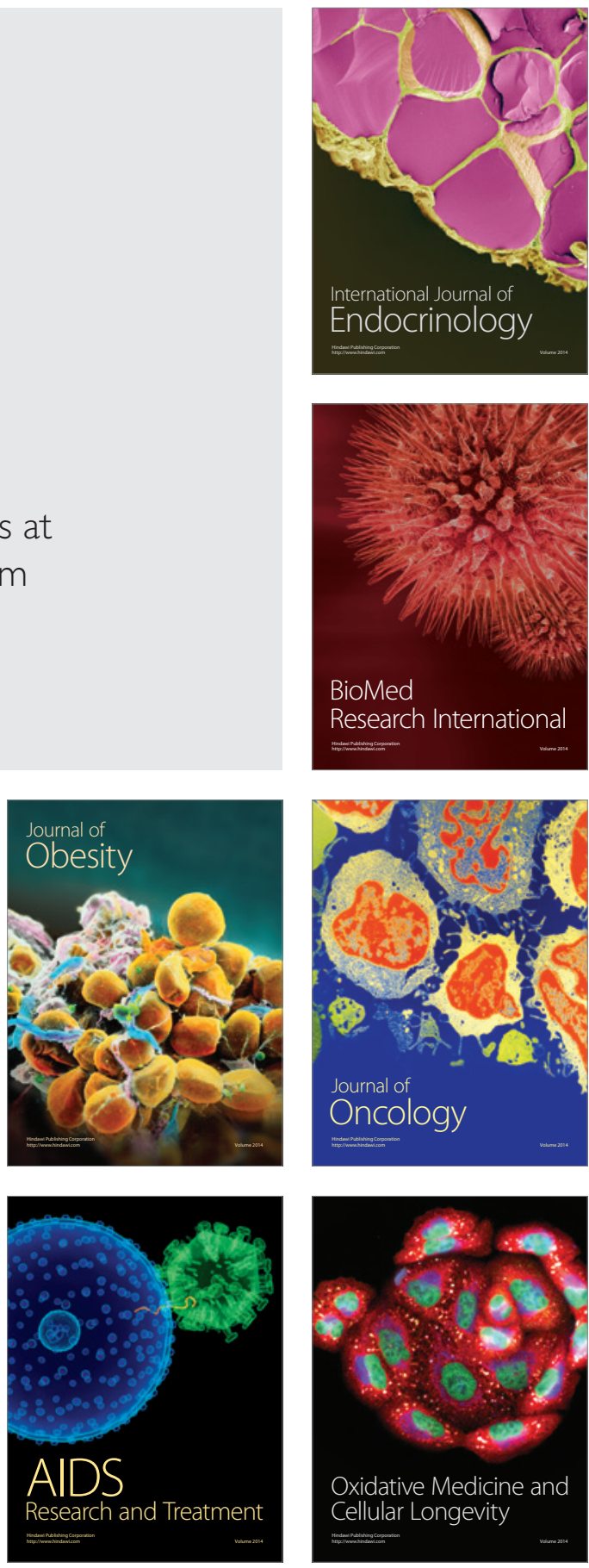